\title{
Iubește-ți Statul! O perspectivă criminologică și de drept penal
}

\author{
Lector univ. dr. Andra-Roxana Trandafir \\ Facultatea de Drept, Universitatea din București
}

\begin{abstract}
Rezumat: Articolul prezintă, pentru publicul nejurist, o scurtă istorie a diferitelor forme ale infracțiunii de trădare în țara noastră, arătând modalitatea în care perspectiva legiuitorului asupra valorilor sociale protejate prin intermediul legii penale a fost influențată de evoluția societății și a regimului politic.
\end{abstract}

Cuvinte cheie: trădare, infracțiuni contra securității naționale, cetățenie

\section{Love your State! A criminological and criminal law perspective}

\begin{abstract}
The paper presents, for the general population, a short history of the different forms of treason in Romania, showing that the legislator's perspective on the protected social values by the criminal law was influenced by the evolution of the society and of the political regimes.
\end{abstract}

Key words: treason, offences agains national security, citizenship

La primul curs de criminologie pentru studenții din anul al II-lea de la Facultatea de Drept, aceștia află care sunt sensurile noțiunii de crimă. Discuția ajunge repede la Garofalo și ale sale delicte naturale - cele care aduc atingere sentimentelor morale de bază, cum sunt mila și cinstea -, adică, în primul rând, omorul și furtul. Totuși, la întrebarea „care este singura faptă care a fost pedepsită de toate societățile, chiar și cele primitive?", răspunsul nu este la fel de ușor. Trecând printr-un istoric al infracțiunilor sus-amintite, studenții ajung la concluzia că fiecare societate are ca prim obiectiv să-și conserve existența; prin urmare, doar trădarea poate fi infracțiunea comună.

Formele de trădare cunoscute de sistemele de drept sunt variate. De la escaladarea unui zid într-una din versiunile legendei lui Romulus și Remus, trecând printr-o suită de acțiuni reprobabile la adresa monarhiei (a se vedea supliciul lui Damiens) și până la modalităţile moderne de comitere a faptei, trădarea a păstrat totuși, din punct de vedere criminologic și penal, câteva trăsături ce o delimitează de alte infracțiuni.

Reglementarea trădării în țara noastră cunoaște o istorie interesantă. Până la adoptarea Codului penal „Carol al II-lea”, diferite forme de trădare erau prevăzute pe larg în legislațiile din Vechiul Regat (,verice român va fi uneltit machinațiuni...”), Transilvania și Bucovina. Unificarea legislativă din 1936 a păstrat, în ceea ce privește trădarea, multiple elemente din aceste reglementări, plasând o serie de infracțiuni cu această denumire la începutul Părții speciale (cea care definește faptele penale) a Codului penal, în capitolul dedicat crimelor și delictelor contra siguranței exterioare a Statului. Plasarea acestor infracțiuni la începutul Codului penal arată importanța acordată ocrotirii Statului român relativ recent format.

Preocupându-se de găsirea unui criteriu de distincție între trădare și spionaj (problemă ce caracteriza și legislațiile din Franța și Germania), pornind de la cazuri celebre (Dreyfus, Schwartz, Boisson etc.) și de la mai multe teorii propuse, Codul penal „Carol al II-lea” a ales, ca fiind cea mai relevantă, naționalitatea infractorului - doctrină nouă de inspirație franceză, preluată deja în țara noastră printr-o lege din 1930 - pentru a delimita cele două categorii de fapte. Trădarea, în configurația acestei legislații, era întotdeauna o crimă, în timp ce spionajul reprezenta un delict și era pedepsit, deci, mai puțin sever. 
Prima infracțiune de trădare astfel reglementată îl pedepsea cu moartea pe cetățeanul român ce săvârșea vreo faptă în scop de a supune teritoriul Statului sau o parte din el suveranității unui stat străin sau de a suprima ori știrbi independența Statului ori de a distruge unitatea Statului. Alte forme de trădare se pedepseau cu munca silnică pe viață ori pe o altă durată sau cu temniță grea; o reglementare din 1948 a introdus pedeapsa cu moartea pentru mai multe categorii de fapte. Obligația de fidelitate (și, de ce nu, de iubire) față de Stat era văzută așadar ca una dintre cele mai importante îndatoriri ale cetățeanului român.

Codul penal din 1969 a păstrat infracțiunile contra siguranței statului la începutul Părții speciale. Trădarea propriu-zisă, definită ca intrarea în legătură cu un stat străin, organizație străină sau agenți ai acestora, comisă într-unul din scopurile de mai sus, era urmată de trădarea prin ajutarea inamicului și trădarea prin transmitere de secrete. Categoriile de persoane care puteau comite infracțiunile includeau, pe lângă cetățenii români, persoanele fără cetățenie care domiciliau în România. Infracțiunile erau pedepsite cu moartea - reprezentând chiar una dintre justificările menținerii acestei pedepse în Codul penal - și confiscarea totală a averii, iar uneori cu închisoarea între 15-20 de ani. O infracțiune aparte de trădare era cea realizată prin refuzul înapoierii în țară, introdusă în Codul penal în 1970, dar abrogată câțiva ani mai târziu. Modificările ulterioare ale infracțiunilor, realizate în special în 1996 au vizat, în esență, pedepsele. Dosarele penale din perioada comunistă au vizat infracțiunea de trădare prin transmitere de secrete și, uneori, pe cea de trădare; unele cereri de modificare a hotărârilor astfel pronunţate au fost judecate de instanțe chiar și în anul 2015.

Codul penal în vigoare (din 2009) a adus o schimbare de paradigmă în ceea ce privește infracțiunile de trădare. Fără a le considera mai puțin importante, legiuitorul a ales să le plaseze spre finalul Părții speciale a Codului, iar nu la început, aducând infracțiunile contra persoanei în Titlul I, cu motivarea că această abordare ,reflectă concepţia actuală privind locul individului şi al drepturilor şi libertăţilor acestuia în ierarhia valorilor care se bucură de protectie, inclusiv prin mijloace penale" (cf. Expunerii de motive a Comisiei de elaborare a Codului penal). Trădarea, în toate formele sale - aproape neschimbate față de Codul penal din 1969 - poate fi comisă doar de un cetățean român, cea mai gravă fiind cea comisă prin ajutarea inamicului.

Discuția de la criminologie din anul II avea o continuare: până în 2014, studenții la Drept din anul al III-lea începeau studiul Părții speciale a Codului penal cu faptele de trădare. Schimbarea locului acestora în Cod a atras și încetarea analizării lor ca parte a materiei, suficient de încărcată cu toate celelalte infracțiuni. Studenții sunt totuși avertizați că această mutare și din fericire - absența unor dosare penale recente care să aibă un astfel de obiect nu înseamnă, în vreun fel, că ar trebui ignorate ori considerate imposibil de repetat.

Articolul a fost publicat în Dilema Veche $n r .841$ din 2-8 aprilie 2020 și preluat ulterior în revista online a Facultății de Drept, $\underline{A U B D}-$ Forum juridic nr 1/2020. 